\title{
Impact of organisational preferential treatment and employees' preference for merit on job involvement of civil servants in Ekiti state
}

\author{
Ogunleye, Adedeji Julius ${ }^{1}$, Osagu, Judith Chineye ${ }^{2}$, Oluwajuyitan, Femi Raphael ${ }^{1}$ \\ ${ }^{1}$ Department of Psychology, Faculty of the Social Sciences, Ekiti State University, Ado Ekiti, Nigeria \\ ${ }^{2}$ Department of Psychology, Faculty of Social Science and Humanities, Federal University, Oye Ekiti, Nigeria
}

Email address:

dr.ajogunleye@gmail.com (A. J. Ogunleye)

To cite this article:

Ogunleye, Adedeji Julius, Osagu, Judith Chineye, Oluwajuyitan, Femi Raphael. Impact of Organisational Preferential Treatment and Employees' Preference For Merit on Job Involvement of Civil Servants in Ekiti State. American Journal of Applied Psychology.

Vol. 3, No. 6, 2014, pp. 144-150. doi: 10.11648/j.ajap.20140306.15

\begin{abstract}
The study examined the impact of organisational preferential treatment and employees' preference for merit on job involvement of workers in Ekiti State Civil Service. Two hundred (200) participants drawn from the Ekiti State Civil Service responded to three instruments used in this study. A total of five hypotheses were tested using Pearson's Product Moment Correlation, Independent t-test and two-way Analysis of Variance (ANOVA). Findings of the study revealed that a positive relationship exists between job involvement and employees' preference for merit. It also showed a positive relationship between job involvement and organisational preferential treatment. There was no significant influence of organisational preferential treatment and employees' preference for merit on job involvement. Each of the independent variables has a separate main effect on job involvement. Both employees' preference for merit and organizational preferential treatment has a positive relationship with job involvement. There was, however, no significant interaction effect observed for both employees' preference for merit and organisational preferential treatment on job involvement of workers. The study concluded that feelings of organisational preferential treatment and job involvement significantly differ along gender while employees' preference for merit does not. Based on the conclusion therefore, recommendations were made.
\end{abstract}

Keywords: Organisational Preferential Treatment, Employee Preference for Merit, Job Involvement, Civil Servants, Ekiti State

\section{Introduction}

In organisational researches, job involvement has emerged as an important variable. It has drawn the attention of management, scientists and organisational psychologists. The variable has been studied in different perspectives in both private organisations and public enterprises. The understanding of the feelings and attitudes of workers to their roles at work is central to the issue of improved management and human resources in an organisation. One may be apt however, to argue that the job involvement ethics of Nigerian workers is poor. Most Nigerian workers, particularly in the civil service/public sectors seem quite lackadaisical in their attitudes to work. Except in offices where there are usually gratifications emanating from monetary rewards for services rendered by the public officers, most of the officers do not resume to their offices in good time, close earlier than scheduled, and generally seem un-involved in their jobs. In spite of the considerable steps taken to improve on the poor job involvement ethics experienced in Nigeria, the results have not been impressive.

The importance of workers to organisations is underlined by the popular saying that "you cannot take the worker out of the work, but you can definitely take out the work of the worker". People are needed at the helm of affairs in organizations and these people need all the encouragements they can get in order to perform well on their job. They need to have a high sense of identification with their job before one can talk about meeting organisational goals.

In a multi-ethnic country like Nigeria where working conditions may be riddled with the problem of in-group sentimentality, the idea of a conducive and fair work station may be nothing more than a mere illusion. 
Industrial psychologists have carried out studies linking job involvement to various variables. For example, ChinChih Ho, Brian Oldenburg, Gary Day and Jing Sun (2012) studied the link between job involvement, work values, and organizational commitment, Gilker and Darzi (2013) studied the relationships between job satisfaction, job involvement and sense of participation, while Rizwan, Khan and Saboor (2011) attempted a study of the link between job involvement and job performance. However, little effort has been dedicated to the study of the relationship between organisational preferential treatment, employees' preference for merit and job involvement. The investigation of these variables in this study has practical usefulness not only to students in achievement areas but also to organisations in the choice of employment and employee gratification techniques. The popular issues of injustice and lack of fair-play can be singled out as one of the major factors that inhibit job involvement among workers and unless efforts at understanding the dynamics of workers in the world of work is made, organizations and group interrelationships will continue to be fraught with problems.

Relevant theories for understanding the relationship between job involvement and its antecedents and outcome variables includes: The expectancy theory, the motivational theories, the causality theories and the integrated theories. The expectancy theory (Vroom, 1964) suggests that administrators should make good use of personal expectancy to inspire employees. This is based on the rudimentary concept that inclination for an individual's action is determined by possible expected results and the relationship between the results and the action adopted. Integrated theory (Rabinowitz and Hall, 1977) relates job involvement to three classes of working variables: the dispositional approach held by the individual, the situational determined approach held and the influence of the interaction between these approaches In this model, no single class of variable shows a stronger relationship to job involvement than other. That is, both dispositional and situational variables are equally important in explaining job involvement. The motivational approach (Kanungo, 1982) integrates the different approaches to job involvement, including both psychological and sociological factors, using the basic concept that job involvement is affected by the potential for personal socialisation experience and the likelihood that the work environment can satisfy personal demands. Finally, causality theory (Brown, 1996) of job involvement includes antecedents (i.e., personality variables-concept of work ethic), the pivotal mediator role of job involvement, and its consequences such as organisational commitment.

\subsection{Job Involvement}

Job involvement explains the extent to which an individual is personally involved with his or her work role. Job is a combination of identifiable roles played by a worker as a contribution to the accomplishment of organisational goals, while the effort he or she invests in the job refers to the amount of personal resources, both mental and physical; he or she summons to play his or her organisational roles. Thus, when a worker is attuned with his or her job, one expects a corresponding increase in the magnitude of effort he or she injects into the job and a continuous injection of efforts over a period of time.

In discussing job involvement, one can only talk about the degree of job involvement whether high or low. The conceptual definitions of job involvement have been of two basic types: the definition by Lodhal and Kejner (1965) and that of Rabinowitz and Hall (1977). Lodhal and Kejner (1965) defined job involvement as the degree to which a person identifies psychologically with his or her work or the importance of work in his or her total self-image. A person's psychological identification with his or her work may be as a result of his/her early socialisation process during which the individual may internalise the values about the goodness of work.

Maurer (1969), in further support of Lodhal and Kejner's (1965) stance employed the term "work role motivation" to describe job involvement which according to him is the degree to which an individual's work role is important in itself, as well as the extent to which it forms basis of self definition, self evaluation and success. In other words, a worker is job involved when s/he sees himself/herself as a person primarily in terms of the role $s /$ he plays in the organisation, and when the only meaning of success to $\mathrm{him} / \mathrm{her}$ is to excel at the role.

To Rabinowitz and Hall (1977), job involvement may be synonymous with occupational involvement or the commitment to a particular set of tasks or task area where successful role performance is regarded as an end in itself and not a means to an end. With this type of commitment, self esteem will be tested through performance in a particular occupational role, and in terms of an evaluation of intrinsic, rather that extrinsic product of role performance. Stated in another way, the degree of job involvement refers to the extent to which success and failure on the job affects the worker's feeling of self-esteem. In other words, there is job involvement when worker's feeling of self worth is increased by good performance. Lawler and Hall (1970) used the term intrinsic motivation to describe job involvement and by this they refer to the degree to which a job holder is motivated to perform well because of some subjective rewards or secret satisfactory feelings that they expect to receive or experience as a result of performing well. Kanungo (1982) saw job involvement as an individual's perception or beliefs that he or she is identified with his or her job or work. To him, a job means an individual's present work, while work means the individual's work in general.

Saleh and Hosek (1976) proposed four conditions that are to be met before a person can be said to be job involved. These conditions are: the job being of critical importance in personal life, the individual being actively involved in his or her job, the individual recognising the influence of personal performance on self-esteem, and the congruence between work performance and self concept. They further suggested that whenever these four conditions are satisfied, the 
individual can be said to be involved in his or her job.

From these definitions of job involvement, it is pertinent to ask whether the Nigerian employees can be described in any sense as being job involved. This question becomes more pertinent when one considers the direction of views among Nigerian writers who tend to uphold the notion that Nigerian employees are not intrinsically motivated.

Eze (1985), for example, in his study of some Nigerian managers found that an overwhelming 96 percent of his subjects agree that Nigerian workers come to work because of money. This according to him means that money is the overriding end for which Nigerian workers are striving and work is simply a means to that end. Much as it may not be contended that Nigerian employees are extrinsically motivated, the subject of Eze's (1985) study should be extended to include the workers themselves instead of management personnel alone who, due to their relatively advantageous socio-economic position, could have been exaggerating or underestimating what makes an average Nigerian worker tick.

\subsection{Preferential Treatment}

This can be defined as job or employment preference subjectively given to a race, ethnicity, or gender. Preferential treatment in a work place refers to the practice of favouritism. This occurs when the leader in an organisation displays some forms of biases towards those workers whom they are socially and ethnically connected with, to the detriment of other workers and overall performance in the firm. In other words, it refers to an individual being treated superior to others, the reason not being because they are better on the job than the others.

Nzimiro (1975) pointed out that there was a particular group of people in the Nigerian academic society, "the intellectual ordinary men" who were extremely reactionists and inward looking. Members of this group would debase the principles and ethics governing appointment and promotions and reserve vacancies for their tribesmen. According to Eze (1978) the compulsive attainment of these men in their ethnic group aspiration, their sectional ideologies and philosophies, makes it difficult for them to function effectively with devotion and commitment. This ethnicity has led to negative attitude to work often found among public sector officials.

Adelola (1983) observed that preferential treatment is a correlate of job involvement among Nigerian workers. According to this scholar, progress in the organisation in which s/he works are not quality and quantity of work done, rather such indices of progress as promotion, salary increment, and further training are based on ethnicity, romantic affiliation, monetary gratification, religious affiliation, etc. In this regard, what matters is who the worker knows and not what he knows. He explains further that the belief of Nigerian employees in preferential treatment represents the cognitive aspect of their attitude towards their places of work viz-a-viz the gratification of the whole sets of needs with which they enter the organisation. In essence, the preferential treatments exist when decisions that are connected with employee progress are on the basis of certain extra-organisational relationships (e.g. ethnic affiliation, sexual/romantic affiliation, monetary gratification, religious affiliation, favouritism/nepotism, etc).

As a component of preferential treatment, ethnicity involves a persistent, compulsive and subjective manoeuvre to favour employees from one's ethnic group in matters connected with progress in the organisation. Eze (1978) describes tribalism as people's orientation, attachment or loyalty to their ethnic group, and a sense of belongingness and identification with such a group. Another component of preferential treatment is monetary gratification. This involves persistent and subjective manoeuvres to favour employees as a result of gratification in terms of monetary bribery. Here, an employee is favoured not based on his or her skills and effectiveness on the job, but as a result of the money he or she offers a recipient, usually the boss. This means that a worker that does not have the money to secure his or her entitlements in the organisation may never get them even when his or her contribution to the organisation is unquestionable. Sexual/romantic affiliation is yet another component of preferential treatment. It is one of the subjective reasons why some decisions are taken in organisations concerning workers' rewards. The concepts of objectivity and fair play are often jettisoned for a subjective process of rewarding a worker for work not done due to an office affair between the boss and such a subordinate (often, the opposite sex).

\subsection{Preference for Merit}

Merit is not easy to define and measure. It often requires difficult subjective evaluations. At some point, someone has to make a judgement about an employee's relative merit. Sometimes, it is even difficult for employees to make a distinction between merit and favouritism. This is because it is so hard to measure in an objective way.

Promotions based on merit have an advantage of advancement of workers who are best qualified for that particular position. This is why when workers are applying for a position; such a worker's past performance is also considered to know whether he or she is fit for that new position (Encina, 2006).

Preference for merit over favouritism in an organisation has numerous advantages. These advantages include:

1 Employee job-related abilities can be better matched with jobs to be filled,

2 Performance is fostered by it,

3 People can be hired for a specific job rather than for ability to be promotable, and

4 Motivated and ambitious employees can be rewarded for outstanding performance.

These advantages notwithstanding, there are also so many disadvantages of employee and organisation's preference for merit. These include:

1 Supervisors might decide to reward their favourites rather than the best employee with merit ratings that are high in order for them to occupy a position, 
2 There might be disruptive conflict resulting from workers competition for merit ratings,

3 Merit and abilities are not easy to measure in an objective and impartial way thus ratings might be partial, and

4 There might also be an introduction of unlawful discrimination into the merit evaluation (Encina, 2006).

Despite these disadvantages however, Cose (1995) posited that organizations should strive to always give preference for merit its pride of place in the scheme of organizational operations and reward mechanisms.

Findings on gender differences on job involvement are varied. However, Madsen, Miller and John (2005), found significant correlations between social relationships and gender and they also attributed the difference in employee motivation between males and females to how each gender perceives work.

Men were said to place a higher value than women do on instrumental values such as basic salaries and bonuses; whereas, women place more importance than men do on interpersonal relationships at the work place such as respectful treatment by the employer, and the possibility of reconciling work and family life.

Based on the discussions above therefore, this research tested the following hypotheses:

1 There will be a significant relationship between employees' preference for merit principle and job involvement,

2 There will be a significant relationship between organisational preferential treatment and job involvement,

3 There will be a significant interaction effect of employees' preference for the merit principle and organisational preferential treatment on job involvement,

4 There will be a significant difference between male and female civil servants on employees' preference for the merit principle and organisational preferential treatment, and

5 There will be a significant difference between male and female civil servants on job involvement.

\section{Method}

\subsection{Research Participants}

200 junior civil servants were randomly selected from the various departments in three different government ministries based in Ado-Ekiti, Ekiti State. 55\% of the participants were males (111 males) while $44.5 \%$ were females ( 89 females). The participants' age range is between ages 23 and 51 years. The participants' years in service ranges between 3 to 14 years. Their educational qualification ranges from secondary school leaving certificate to a masters' degree in various disciplines. $28.5 \%$ (57 persons) of the participants were single while the remaining $71.5 \%$ (142 persons) were married.

\subsection{Research Procedure}

The research made use of a stratified random sampling method. Copies of the questionnaire were administered individually by the researchers. A copy of the questionnaire contained four sections section 'A' contained questions about the biographic data or research participants, section ' $B$ ' contained the measure of organisational preferential treatment, section ' $\mathrm{C}$ ' contained the employee preference for merit principle scale, while section ' $D$ ' contained job involvement scale. Of the two hundred and forty-three copies of questionnaire administered, only two hundred were properly filled, thus these were scored and analysed. The Pearson Product Moment correlation statistic was employed to determine the relationship between the variables under study. The two-way Analysis of Variance (ANOVA) was also employed to determine the interaction effect of the independent variables on the dependent variable. Finally, the independent groups' t-test was used to compare the participants' mean scores along sex (gender).

\subsection{Variables}

Three variables - organisational preferential treatment, employee preference for merit and job involvement were used for the study. Organisational preferential treatment and employees' preference for merit were the independent variables while job involvement is the dependent variables.

\subsection{Measures}

Three instruments were used to measure the variables of interest. The measures are described below.

\subsection{Preference for Merit Principle (PMP) Scale}

This scale was used to measure participants' preference for merit principle. The scale was developed by Bobocel, SonRing, Davey, Stanley and Zanna in 1998. It is a 15 item instrument with a seven point anchor rating scale ranging from (i) strongly disagree to (vii) strongly agree. The reliability coefficient of the scale is Cronbach's alpha .70, putting the scale at a level that is conventionally acceptable (Nunnally, 1970).

\subsection{Organisational Preferential Treatment Scale}

To measure preferential treatment, Preference for Merit Principle Scale (PMP) was adapted. The adaptation was certified useful for measuring the construct at face validity. The scale is a 15 item instrument with a seven point anchor rating ranging from (i) strongly disagree to (vii) strongly agree. The coefficient of the spilt-half reliability obtained is .53 for males and .84 for females. The internal reliability coefficient was calculated using 30 respondents in a pilot study. Evidence for construct validity of the scale would hold if scores on the PMP Scale both correlate positively with scores on the theoretically similar scale. The scale provides both concurrent and predictive validity evidence for the PMP Scale. The PMP Scale is able to predict participants' attitudes 
towards a social policy, as theoretically expected, on the basis of the PMP scores collected for this study.

\subsection{Job Involvement Scale (JI)}

This scale was developed by Lodhal and Kejner (1965) to measure the extent to which a person's work performance affects his/her self-esteem. The scale is an inventory comprising of 23 items (both direct and reverse score items) and a five point anchor rating ranging from (i) strongly disagree to (v) strongly agree. Lodhal and Kejner (1965) obtained Spearman-Brown internal reliability co-efficient of .72 and .80 for females and males respectively. The coefficient of test-retest reliability in an interval of 72 days is .92. Concurrent validity for the scale was obtained by correlating the JI Scale with the Job Descriptive Index (JDI) (Smith et al, 1969). The reported norms are the means scores obtained by workers in the general population from a survey carried out in the United States of America, and another carried out in Nigeria. For America sample: $(n=70)=42.62$. For Nigeria sample: $(n=600)=41.76$.

\section{Results}

The results of the study are presented below.

Table 1a. Descriptive analysis of biographic characteristics of participants

\begin{tabular}{lcc}
\hline Demographics & Frequency & Percentage \\
\hline Gender & & \\
Male & 111 & 55.5 \\
Female & 89 & 44.5 \\
Total & 200 & 100 \\
\hline
\end{tabular}

Table 3. A summary table of two-Way Analysis of Variance (ANOVA) showing the interaction effect of Organisational Preferential Treatment (OPT) and Employees' Preference for Merit (EPM) on Job Involvement

\begin{tabular}{|c|c|c|c|c|c|}
\hline Source & Type III sum of square & df & Mean Square & $\mathbf{F}$ & Sig. \\
\hline Organisational Preferential Treatment (OPT) & 5681.333 & 1 & 5681.333 & 43.789 & $\mathrm{P}<0.01$ \\
\hline Employees’ Preference for Merit (EPM) & 2149.199 & 1 & & & \\
\hline $\mathrm{EPM}^{*}(\mathrm{OPT})$ & .183 & 1 & 2149.199 & 16.565 & $\mathrm{P}<0.01$ \\
\hline Error & 25429.649 & 196 & & & \\
\hline Total & 1220479.000 & 200 & .183 & .0001 & $\mathrm{P}>0.05$ \\
\hline Corrected Total & 43133.875 & 199 & 129.743 & & \\
\hline
\end{tabular}

Dependent Variable: Job Involvement

Table 4. A table showing mean scores, standard deviation and t-test analysis of respondents score on EPM, OPT and job involvement along sex

\begin{tabular}{|c|c|c|c|c|c|c|c|}
\hline Variables & Gender & $\mathbf{N}$ & Mean & Std deviation & df & $\mathbf{t}$ & Sig (2-tailed \\
\hline \multirow{2}{*}{ EPM } & Males & 111 & 81.47 & 12.07 & \multirow{2}{*}{198} & \multirow{2}{*}{0.17} & \multirow{2}{*}{$\mathrm{P}>0.05$} \\
\hline & Females & 89 & 78.80 & 13.95 & & & \\
\hline \multirow{2}{*}{ OPT } & Males & 111 & 76.01 & 12.32 & \multirow{2}{*}{198} & \multirow{2}{*}{2.51} & \multirow{2}{*}{$\mathrm{P}<0.05$} \\
\hline & Females & 89 & 70.24 & 14.85 & & & \\
\hline \multirow{2}{*}{ JI } & Males & 111 & 79.04 & 12.45 & \multirow{2}{*}{198} & \multirow{2}{*}{3.14} & \multirow{2}{*}{$\mathrm{P}<0.05$} \\
\hline & females & 89 & 73.84 & 16.78 & & & \\
\hline
\end{tabular}

Results from the table above revealed that male and female civil servants do not differ significantly on employees' preference for merit $[\mathrm{t}(198)=0.17 ; \mathrm{p}>0.05]$. However, a significant difference exists between male and female civil servants in their job involvements $[\mathrm{t}(198)=3.14, \mathrm{p}<0.05]$ and their organizational preferential treatment $[\mathrm{t}(198)=2.51$; $\mathrm{p}<0.05]$.
Table 1b. Descriptive analysis table showing participants mean and standard deviation scores on Employees' Preference for Merit (EPM), Organizational Preferential Treatment (OPT) and Job Involvement (JI)

\begin{tabular}{llll}
\hline Variable & N & Mean & STD. Deviation \\
\hline $\begin{array}{l}\text { Organisational Preferential } \\
\text { Treatment (OPT) }\end{array}$ & 100 & 8.38 & 6.43 \\
$\begin{array}{l}\text { Employee Performance for } \\
\text { Merit (EPM) }\end{array}$ & 100 & 40 & 7.52 \\
Job Involvement (JI) & 100 & 36.97 & 6.43 \\
\hline
\end{tabular}

Table 2. Correlation table showing the relationship between EPM, OPT and JI

\begin{tabular}{ll}
\hline Variable & Job Involvement (JI) \\
\hline Organisational Preferential Treatment (OPT) & $0.66^{* *}$ \\
Employee Performance for Merit (EPM) & $0.55^{* *}$ \\
\hline
\end{tabular}

Significant at $\mathrm{P}<0.01$, df (198).

The above table shows a positive relationship between organisational preferential treatment and job involvement $[\mathrm{r}$ $(198)=0.66, p<0.01]$. Furthermore, there was also a positive relationship between employees' preference for merit and job involvement $[\mathrm{r}(198)=0.55, \mathrm{p}<0.01]$.

\subsection{Test of Between-Subjects Effects}

The table above shows that OPT has a significant main effect on job involvement $[\mathrm{F}(1,199)=43.79, \mathrm{P}<0.01]$. Furthermore, EPM has a significant main effect on job involvement $[\mathrm{F}(1,199)=16.57, \mathrm{P}<0.01]$. However, there was no significant interaction effect of EPM and OPT observed on job involvement at $[\mathrm{F}(1,199)=0.001, \mathrm{P}>0.05]$.

\section{Discussion of Results, Conclusion and Recommendation}

\subsection{Discussion}

From the results of the present study, it was found that 
both organisational preferential treatment and preference for merit have significant main effects on job involvement. This shows that the level of job involvement of an employee who believes in preferential treatment varies. It also shows that the level of involvement of workers varies depending on their differing levels of perception of organisational preferential treatment. In a work environment where fair play is not the yard stick by which workers performance and subsequent award of benefits are measured, an inherently industrious worker might develop a feeling of "having nothing to work for" resulting from the worker's belief rewards and benefits will most likely be awarded to the "manager's favourites", who does not merit such benefits.

The separate and combined effects of both organisational preferential treatment and beliefs in the merit on job involvement of employees are explained in the following examples:

The first example is the job conscious and hard working employee who prefers the merit principle. He or she is likely to be fully and consciously participatory in work related activities with the assurance that progress in the organisation were higher on the level of workers contribution to the organisation. An ideal organisation for such an individual is an organisation where the level of organisational preferential treatment is low. In this regard, a worker's belief in the merit principle is shown to have effects on his job involvement, supporting the first hypothesis.

Another example is that of another hard working worker who equally prefers the merit principle but who works in an organisation where favouritism is likely to wear off the worker's diligence at work; as such virtue is not reinforced with benefits. In this case, only the very principled worker remains diligent while others may consider the option of moving to another organisation with better working conditions. Yet another example is that of a worker who does not believe much in the merit principle, working in an organisation where hard work is not adequately rewarded and preferential treatment is on the high. Such a worker may choose not to be much involved in his or her job, as advancements in the organisation is based on any kind of relationship or agreement between employee and superiors. Instead of putting efforts into his job, the worker is motivated to put more efforts into pleasing the bosses.

Based on the results of this study, employees who have a lesser belief in the merit principle were found to be less involved in their job compared to employees who believe more in the merit principle. Surprisingly enough, employees who perceived less preferential treatment in the organisation where they work are not so much involved in their job compared to employees who perceived a lot of preferential treatment in the organisation where they work. The hypothesis that there will be a significant relationship between organisational preferential treatment and job involvement of workers are supported by the second and third examples above. This is in agreement with the assertion made by Eze (1978), who opined that preferential treatment can lead to a negative attitude to work often found among public sector officials. This illustration can be a plausible reason why the combination of the level of belief in the merit principle and perceived organisational preferential treatment did not determine the level of involvement on the job.

Another inference made from the results of this study is that there is no significant difference between male and female civil servants with respect to belief in the merit principle. This connotes that belief in the principle is not gender-based. This result is consistent with a previous research by Major and Deaux (1982) which concludes that females are oriented towards the interpersonal aspects of a relationship and seek to establish or maintain friendly relations with their partners, which is why they obey the equality principle. In contrast, males are thought to be more focused on the task and seek to solve the problems, which is why they obey the equality principle.

The results of this study suggest that even though differences in belief in merit principle could be as a result of some unique personal characteristics, it cannot be attributed to gender differences. On the other hand, the results of the study showed a significant difference between males and females in feelings of organisational preferential treatment. Male employees were found to have more feelings of organisational preferential treatment than female employees.

Researches often debate whether job involvement occurs as a result of value orientations occurring as an individual difference variable and a personal characteristics that differs from person to person and gender to gender (Dubin, 1956; Lodhal and Kejner, 1965) or whether it occurs as a function of the situation (Bass, 1965; Vroom, 1962) or as a result of an individual-situation interaction (Lawler and Hall, 1970; Muchinsky, 1990).

The results of this study however, support the positions of Dubin, (1956), and Lodhal and Kejner, (1965) as male employees were found to exhibit higher levels of job involvement than their female employee counterparts. This is in tandem with the predictions of the fifth hypothesis of the study.

\subsection{Conclusion}

The importance of fairness and justice in the treatment of personnel in organisations has been well emphasised in the course of this study. Therefore, on the basis of the results obtained, it can be empirically concluded that:

1 There is a significant relationship between employee preference for the merit principle and job involvement,

2 There is a significant relationship between organisational preferential treatment and job involvement,

3 Although, there is a significant main effect of both employee preference for the merit principle and organisational preferential treatment on the job involvement, there is no significant interaction effect of both variables on job involvement,

4 While employees' preference for merit is not genderbased, employees feelings of organisational preferential treatment is gender-based. Males have more feelings of organisational preferential treatment than females, and 
5 Levels of job involvement are gender-based. Male employees exhibit higher levels of job involvements compared to their female employee counterparts.

\subsection{Recommendations}

Based on the conclusions of the study, it is recommended that if organisations believe that keeping their workers motivated and allowing no disgruntlement (through zero tolerance for any form of preferential treatment) can increase the level of job involvement among their workforce, then steps must be taken to ensure that through the use of levels of hard work and diligence at work as yardsticks, employees should get their 'just' dues. Workers should not be allowed to reap where they have not sown.

In order to enhance employees' feelings of job involvement, organisations should strive to create jobs that are meaningfully challenging and interesting, and ensure that excellent performance is recognised and rewarded.

\section{References}

[1] Adelola, A. (1983). Preferential treatment as a correlate of job involvement among Nigeria employees. A paper presented at the graduate seminar of the Department of Psychology, University of Lagos. May 5, 1983.

[2] Bass, B. M. (1965). Attitudes towards work. In B. M. Bass (ed.), Organisational Psychology (4 ${ }^{\text {th }}$ ed.) (Pgs. 393-410). Boston: Houghton Mifflin.

[3] Bobocel, D. R., Son Ring, L. S., Davey, L. M., Stanley, D. J., \& Zanna, M. P. (1998). Justice-based opposition to social policies: Is it genuine? Social Psychology Journal. 75(2): 653669.

[4] Brown, S. P (1996). A meta-analysis and review of organisational research on lob involvement. Psychological Bulletin. 120 (2): 235-255.

[5] Chin-Chih, Ho, Brian Oldenburg, Gary Day \& Jing Sun (2012). Work values, job involvement and organizational commitment in Taiwanese Nurses. International Journal of Psychology and Behavior Sciences, 2(3): 64-70.

[6] Cose, E. (1995, April 3). The myth of meritocracy. Newsweek, 34.

[7] Encina, G. B. (2006). Labour management in Agriculture: Cultivating personnel productivity (2nd ed.). California: National Association for County Agricultural Agents (NACAA). University of California.

[8] Dubin, R. (1956). Industrial workers' world: A study of the "central life interests" of industrial workers. Social Problem. 3 (1): 131-142.

[9] Eze, N. (1978). Ethnic group affiliation and work motivation in the third world nations. Management in Nigeria. 14 (9): 823.
[10] Eze, N. (1985). Sources of motivation among Nigerian manager. The Journal of Social Psychology. 125 (3): 341-345.

[11] Gilker, Nasir A. \& Darzi, Javid A. (2013). Job InvolvementSense of Participation-Job Satisfaction: A triangular framework. IOSR Journal of Business and Management, 6(6): $41-47$

[12] Kanungo, R. N. (1979). The concepts of alienation and involvement revisited. Psychological Bulletin. 85(1): 119-138.

[13] Kanungo, R. N. (1982). Measurement of job and work involvement. Journal of Applied Psychology. 67 (3): 341-349.

[14] Lawler, E. E., \& Hall, D. T. (1970). Relationship of job characteristics to job involvement, satisfaction and intrinsic motivation. Journal of Applied Psychology. 54 (4): 305-312.

[15] Lodhal, T. M., \& Kejner, M. (1965). The definition and measurement of job involvement. The Journal of Applied Psychology. 49 (1): 24-33.

[16] Madsen, S.R., Miller, D. \& John, C. R. (2005). Readiness for organisational change: do organisational commitment and social relationships in the workplace make a difference? Human Resource Development Quarterly, 16 (2): 213-233.

[17] Major, B. \& Deaux, K. (1982). Individual differences in justice behaviour. In Y. Greenberg and R. L. Cohen (Eds.), Equity and Justice in Social Behaviour. (2 ${ }^{\text {nd }}$ ed.) (Pgs. 43-76). New York: Academic Press.

[18] Maurer, J. G. (1969). Work role involvement of industrial supervisors. ( $3^{\text {rd }}$ ed.). New York: Bereau of Business and Economic Research, Michigan State University.

[19] Muchinsky, P. M. (1990). Psychology applied to work: An introduction to industrial and organisational psychology $4^{\text {th }}$ ed.). Monterey, CA: Brooks/Cole Publishing Co. pp. 412-428.

[20] Nunnally, J. C. (1970). Introduction to Psychological Measurement. New York: McGraw-Hill

[21] Nzimiro, J. (1975). Ethnic balancing and loss of academic freedom. Daily Times Newspaper Publications, Nigeria.

[22] Rabinowitz, S. \& Hall D. (1977). Organisational research on job involvement. Psychological Bulletin. 84 (2): 265-288.

[23] Rizwan, M., Khan, Dil Jan \& Saboor, Fawad (2011). Job Involvement with Employees' Job Performance: Moderating role of attitude. Journal of Business and Management, 3(8): $77-85$.

[24] Saleh, S. D., \& Hosek, J. (1976). Job involvement: Concepts and measurements. Academy of Management Journal. 19 (2): 213-231.

[25] Smith, P. C., Kendal, L. M. \& Hulin, C. L. (1969). The measurement of satisfaction in work and retirement. Chicago: Rand McNelly.

[26] Vroom, V. H. (1962). Ego involvement, job satisfaction and job performance. Personnel Psychology, 15 (2): 159-177.

[27] Vroom, V. H. (1964). Work and motivation. San Fransisco, CA: Jossey-Bass. 